\title{
Selected risk factors for atherosclerosis in children and their parents with positive family history of premature cardiovascular diseases: a prospective study
}

\author{
Elzbieta Pac-Kozuchowska', Paulina Krawiec ${ }^{1}$ and Ewelina Grywalska ${ }^{2^{*}}$ (1)
}

\begin{abstract}
Background: The aim of the study was to evaluate serum parameters of lipid metabolism, homocysteine, soluble adhesion molecules and common carotid artery wall thickness in children from families with early symptoms of atherosclerosis.

Methods: The first stage included 137 pairs of mothers and newborns, and the second 18 children from the same group (age 18-30 months) and their parents (age 21-46 years) with a history of premature coronary artery disease (CAD), as well as 12 age- and sex-matched controls.

Results: During the first stage, inverse correlations were found between birthweight, cord blood concentrations of triglycerides (TG), VLDL cholesterol and apolipoprotein B (Apo B). Serum concentrations of total cholesterol (TC), apolipoprotein A1 (Apo A1), LDL and HDL cholesterol and were significantly higher in female than in male newborns. During the second stage, children from families with a history for premature CAD were shown to present with significantly higher serum concentrations of $T G, V L D L$ cholesterol and lipoprotein $A(L p(a))$ than the controls. Furthermore, their TC correlated positively with vascular cell adhesion molecule-1 (Rs $=0.717, p<0.05$ ) and intracellular adhesion molecule-1 (sICAM-1) levels (Rs=0.833, $p<0.05)$. Moreover, positive correlations were found between maternal carotid intima media thickness (IMT) and TC (Rs $=0.831, p<0.01)$, as well as between paternal IMT and Apo B (Rs=0.692, $p<0.05)$, TG and sICAM-1 (Rs=0.912, $p<0.01)$, TG and sE-selectin ( $R s=0.678, p<0.05$ ).
\end{abstract}

Conclusions: Serum $L p(a)$ may serve as a maker of cardiovascular risk in children and adolescents.

Keywords: Atherosclerosis, Cardiovascular risk, Lipid profile

\section{Background}

Although cardiovascular diseases based on atherosclerosis, like ischemic heart disease or stroke, manifest in adulthood, there is a compelling evidence that the process of atherosclerosis begins in childhood and progresses to measureable vascular changes in adulthood $[1,2]$.

The pathogenesis of atherosclerosis has undergone many changes over the last decades. The traditional viewpoint established atherosclerosis as a localized cholesterol storage disease with flow-limiting arterial stenosis

\footnotetext{
* Correspondence: ewelina.grywalska@gmail.com

${ }^{2}$ Department of Clinical Immunology and Immunotherapy, Medical

University of Lublin, Chodzki 4a Street, 20-093 Lublin, Poland

Full list of author information is available at the end of the article
}

[3]. We currently understand atherosclerosis as a chronic inflammatory process of arterial wall resulting from interplay of lipid metabolism imbalance, maladaptive immune response and genetic alterations [3-5].

Traditionally cardiovascular modifiable risk factors included cigarette smoking, hypercholesterolemia, hypertension and diabetes [6-8]. Approximately 20\% of cardiovascular events occur in the absence of above mentioned conventional risk factors [9].

Intense investigations on novel risk factors are conducted to define cardiovascular risk in individuals without traditional risk factors. Recent studies have shown several important non-traditional risk factors for atherosclerosis including hs-CRP, homocysteine, small dense 
low density lipoprotein particles (small dense LDL), oxidized low density lipoprotein (oxy-LDL), apolipoprotein A1 and B (Apo A1 and Apo B), lipoprotein a (Lp(a)), fibrinogen and triglyceride-rich lipoprotein remnants [10].

Non- modifiable atherosclerosis risk factors include age, gender and family history of premature cardiovascular diseases (CVD). The growing body of evidence indicates that the family history of premature coronary artery disease (CAD) is an independent risk factor for CVD and significant predictor for CAD [11-14]. According to The Third Report of the Expert Panel on Detection, Evaluation, and Treatment of the High Blood Cholesterol in Adults (ATP III) family history of premature CAD, specify as myocardial infarction or sudden death before 55 years of age in father or other male firstdegree relative, or before 65 years of age in mother or other female first-degree relative) was found as the major risk factor of CAD [15]. Accumulation of family history of premature CVD with obesity, hypertension and diabetes is often accompanied. Thus, lifestyle intervention including dietary modification, increased physical activity, weight control and smoking cessation may be more efficient when undertaken by the entire family than the individual due to built-in support mechanism of the family [16].

The aim of the study was to evaluate the parameters of lipid metabolism, i.e. triglycerides (TG), total cholesterol (TC) and its fractions: HDL, LDL and VLDL cholesterol, apolipoprotein A1 and B (Apo A1 and Apo B), lipoprotein(a) (Lp(a)), homocysteine, soluble adhesion molecules (sICAM-1, sVCAM-1 and sE-selectin) in the blood serum and the thickness of common carotid artery wall (IMT) in children from families in which early symptoms of atherosclerosis.

\section{Methods}

The study was performed in two stages. During the first stage, the study group was composed of 137 pairs of mothers and their newborns (74 girls and 63 boys). To the study group we recruited healthy newborns, from pregnancies free of complications, born at term by spontaneous vaginal delivery with Apgar score 8-10 points at first minute after birth. The family history of cardiovascular diseases (ischemic heart disease, stroke) and risk factors for atherosclerosis like obesity, hypertension, type 2 diabetes mellitus and hypercholesterolemia was undertaken from mothers. There were selected 41 of 137 families (29.9\%) with risk factors for atherosclerosis.

In all 137 pairs of mothers and newborns we assessed nutritional status and serum concentrations of TG, TC, HDL, LDL, VLDL, Apo A1, Apo B and Lp(a).

The prospective evaluation of all newborns and their parents was planned in 18 to 30 months after birth. The information about the next stage of the study was sent to all 137 families participated in the first stage of the study. However, only 41 families volunteered to the second stage of the study. In that group we selected 29 families with risk factors for atherosclerosis and 18 with positive history for premature CAD. We presumed that parents who participated in second stage of the study were aware of the cardiovascular disease danger.

Ultimately, in the second stage of the study we included 18 children (8 girls and 10 boys) aged 18 to 30 months and their parents (aged 21-46 years) with positive history for premature coronary artery disease. The control group consisted of 12 age- and sex-matched children without a family history of CAD. In all children and their parents we assessed serum concentrations of TG, TC, HDL, LDL, VLDL, Apo A1, Apo B, Lp(a), homocysteine (Hcy), intracellular adhesion molecule-1 (sICAM-1), vascular cell adhesion molecule-1 (sVCAM1) and sE-selectin.

The blood samples were taken fasting from the cord blood in newborns and from the ulnar vein in children and their parents. The serum the concentration of TG, TC and HDL was determined by the Cormay reagents and the Cobas Mira $S$ analyzer. The concentration of Apo A1, Apo B and Lp(a) was determined by immunoturbidimetric method (Roche and Human). The concentration of homocysteine was determined by ELISA method using Axis Homocysteine EIA Package Insert by Axis-Shield AS. The concentrations of sICAM-1, sVCAM-1 and sE-selectin were determined by ELISA method, with the application of kits human sICAM-1 BMS201, human sVCAM-1 BMS232, human sE-selectin BMS205 (Bender Med Systems Diagnostics GmbH). The concentration of LDL and VLDL was defined by using the formula by Friedewald [17].

To identify early atherosclerotic changes common carotid intima and media combined layers thickness (IMT) was measured with an ATL 3500 ultrasound system with a $12 \mathrm{MHz}$ linear transducer. The IMT was evaluated both on the right and left side, no significant differences were noticed thus the mean IMT value was calculated. A schematic diagram of the study design is presented at Fig. 1.

The statistical analysis of the results was made with application of Statistica 5.1 PL software. The distribution of studied data sets were checked up by Shapiro-Wilk test. The distribution of the examined parameters was skewed, thus Mann Whitney U test was applied for the analysis of the differences between two groups or Kruskal-Wallis ANOVA and multiple comparisons of mean ranks (as post-hoc analysis) for the analysis of differences between more than two groups. The Spearman $\mathrm{R}$ correlation test was used to assess the relationships between the parameters tested. The $\mathrm{p}$ values of $\mathrm{p}<0.05$ were considered statistically significant. 


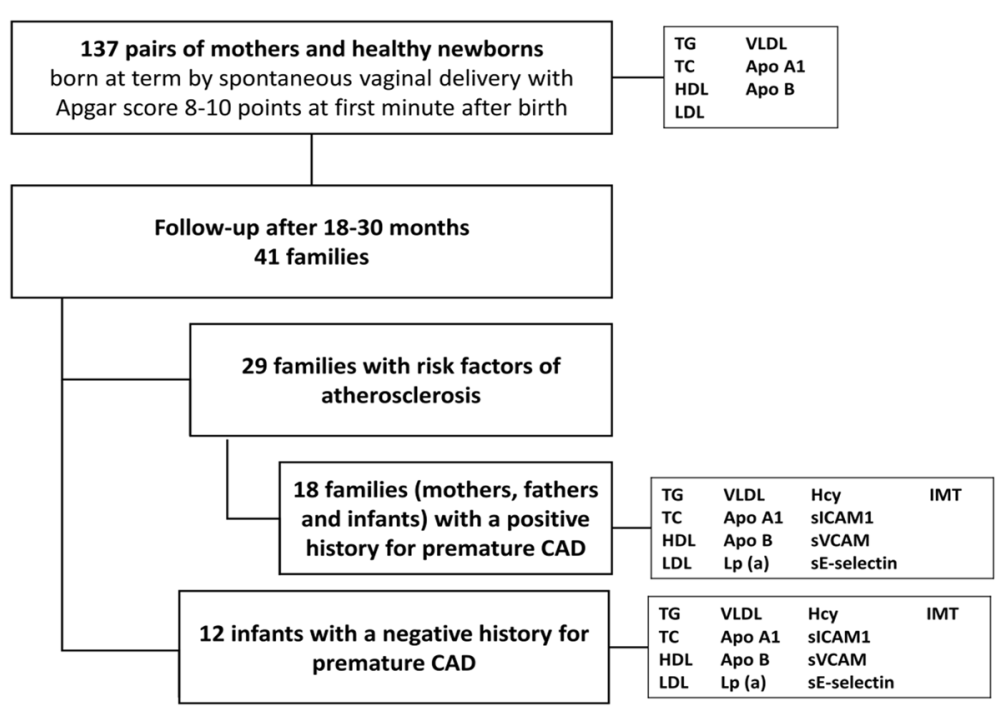

Fig. 1 Schematic diagram of the study design

The written informed consent to this research study was obtained from parents. The paper has been approved by Medical University Bioethical Committee (number KE-0254/74/2009).

\section{Results}

During the first stage of the study, we recruited 137 pairs of healthy mothers and their newborns. Newborns included 74 girls (54\%) and 63 boys (45\%), with the mean birth weight $3268.0 \pm 529.4 \mathrm{~g}$ and mean body length $54.4 \pm 3.1 \mathrm{~cm}$. The mean gestational age was $39.1 \pm 1.5$ weeks.

Table 1 presents the lipid profile and apolipoprotein concentration in newborns and their mothers.

The results, as shown in Table 2, indicated no significant differences in newborns' lipids parameters according to family history for cardiovascular diseases.

In the second stage of the study volunteered 18 families with positive family history for premature CAD.

Table 1 Lipid and apolipoprotein concentrations (means \pm SD) in newborns' cord blood and mothers' serum

\begin{tabular}{lll}
\hline Parameter & Newborns & Mothers \\
\hline TG $(\mathrm{mg} / \mathrm{dl})$ & $58.75 \pm 66.72$ & $221.99 \pm 89.58$ \\
TC $(\mathrm{mg} / \mathrm{dl})$ & $65.05 \pm 21.39$ & $263.58 \pm 58.01$ \\
$\mathrm{HDL}(\mathrm{mg} / \mathrm{dl})$ & $19.63 \pm 8.40$ & $64.23 \pm 15.86$ \\
$\% \mathrm{HDL}$ & $30.74 \pm 9.27$ & $25.20 \pm 7.48$ \\
$\mathrm{LDL}(\mathrm{mg} / \mathrm{dl})$ & $34.12 \pm 14.08$ & $155.14 \pm 49.44$ \\
VLDL $(\mathrm{mg} / \mathrm{dl})$ & $11.46 \pm 9.93$ & $48.83 \pm 17.83$ \\
Apo A1 $(\mathrm{mg} / \mathrm{dl})$ & $86.50 \pm 18.60$ & $232.02 \pm 39.07$ \\
Apo B $(\mathrm{mg} / \mathrm{dl})$ & $37.90 \pm 17.70$ & $149.00 \pm 41.03$ \\
\hline
\end{tabular}

The results, as shown in Table 3, showed significantly higher serum concentration of TG, VLDL and Lp(a) in children aged 18 to 30 months from families with positive history for premature CAD compared to controls. Table 4 compares the serum lipid profile, Apo A1, Apo B, sVCAM-1, sICAM-1, Hcy and sE-selectin concentration and IMT in mothers and fathers of subjects.

In children with a positive family history for premature CAD were found positive correlations between $\mathrm{TC}$ and sVCAM-1 (Rs=0.717, $\mathrm{p}<0.05)$, and TC and sICAM-1 (Rs=0.833, $\mathrm{p}<0.05)$. In mothers we stated significant positive correlation between IMT and TC concentration $(\mathrm{Rs}=0.831, \mathrm{p}<0.01)$. In fathers there were positive correlations between IMT and Apo B ( $\mathrm{Rs}=0.692, \mathrm{p}<0.05)$, TG and sICAM-1 (Rs=0.912, $\mathrm{p}<0.01)$, TG and sE-selectin $(\mathrm{Rs}=0.678, \mathrm{p}<0.05)$.

Lipid profile and concentration of apolipoproteins in newborns' cord blood according to their birth weight is presented in Table 5. A significant correlation was found between body mass at birth and cord blood concentration of TG, VLDL and Apo B. Newborns with the lowest

Table 2 Lipid and apolipoprotein concentrations (means \pm SD) in newborns' cord blood according to family history of CVD

\begin{tabular}{llll}
\hline Parameter & Positive history $(\mathrm{n}=41)$ & Negative history $(\mathrm{n}=96)$ & $\mathrm{p}$ \\
\hline TG $(\mathrm{mg} / \mathrm{dl})$ & $54.73 \pm 45.10$ & $60.47 \pm 73.67$ & $\mathrm{~ns}$ \\
TC $(\mathrm{mg} / \mathrm{dl})$ & $63.39 \pm 16.67$ & $65.76 \pm 22.98$ & $\mathrm{~ns}$ \\
LDL $(\mathrm{mg} / \mathrm{dl})$ & $33.15 \pm 11.49$ & $34.54 \pm 14.96$ & $\mathrm{~ns}$ \\
VLDL $(\mathrm{mg} / \mathrm{dl})$ & $11.31 \pm 8.97$ & $11.52 \pm 10.26$ & $\mathrm{~ns}$ \\
HDL $(\mathrm{mg} / \mathrm{dl})$ & $19.25 \pm 6.49$ & $19.79 \pm 9.04$ & $\mathrm{~ns}$ \\
Apo A1 (mg/dl) & $87.80 \pm 16.78$ & $90.28 \pm 19.18$ & $\mathrm{~ns}$ \\
Apo B (mg/dl) & $36.85 \pm 15.25$ & $38.41 \pm 18.65$ & $\mathrm{~ns}$ \\
\hline ns - non-significant & &
\end{tabular}


Table 3 Comparison of selected risk factors in 18- to 30-month \pm -old children with a positive history for premature CAD and controls (means $\pm \mathrm{SD}$ ); $2^{\text {nd }}$ stage of the study

\begin{tabular}{|c|c|c|c|}
\hline Parameter & Positive history $(n=18)$ & Negative history $(n=12)$ & $p$ \\
\hline$\overline{\mathrm{TG}}(\mathrm{mg} / \mathrm{dl})$ & $105.44 \pm 69.04$ & $83.03 \pm 29.26$ & $<0.05$ \\
\hline $\mathrm{TC}(\mathrm{mg} / \mathrm{dl})$ & $165.56 \pm 30.99$ & $167.83 \pm 33.15$ & ns \\
\hline $\mathrm{HDL}(\mathrm{mg} / \mathrm{dl})$ & $55.46 \pm 14.28$ & $47.35 \pm 11.92$ & ns \\
\hline $\mathrm{LDL}(\mathrm{mg} / \mathrm{dl})$ & $88.96 \pm 37.14$ & $103,87 \pm 32.30$ & ns \\
\hline VLDL (mg/dl) & $21.09 \pm 13.81$ & $16.62 \pm 5.85$ & $<0.05$ \\
\hline Apo A1 (mg/dl) & $154.22 \pm 18.73$ & $147.33 \pm 19.90$ & ns \\
\hline Apo B (mg/dl) & $73.11 \pm 18.82$ & $77.58 \pm 17.59$ & ns \\
\hline $\operatorname{Lp}(\mathrm{a})(\mathrm{mg} / \mathrm{dl})$ & $18.27 \pm 26.11$ & $5.89 \pm 3.65$ & $<0.05$ \\
\hline Hcy ( $\mu \mathrm{mol} / \mathrm{L})$ & $12.20 \pm 2.46$ & $10.67 \pm 2.41$ & ns \\
\hline sVCAM-1 (ng/ml) & $1616.11 \pm 561.92$ & $1516.13 \pm 501.75$ & ns \\
\hline slCAM-1 (ng/ml) & $391.15 \pm 95.28$ & $384.31 \pm 57.96$ & ns \\
\hline sE-selectin (ng/ml) & $58.37 \pm 17.17$ & $72.57 \pm 38.16$ & ns \\
\hline IMT (mm) & $0.43 \pm 0.04$ & $0.39 \pm 0.06$ & ns \\
\hline
\end{tabular}

ns - non-significant

birth weight (2250-2500g), had the highest concentration of these parameters. In female newborns concentration of TC, LDL, HDL and Apo A1 was significantly higher than in male newborns $(\mathrm{p}<0.05)$. There were no correlation between sex and concentration of TG, VLDL and Apo B.

The mean maternal age was $26 \pm 3$ years. In the study group, $64(46.7 \%)$ women were in first pregnancy, 31 $(22.6 \%)$ in their second pregnancy, $22(16.1 \%)$ in third pregnancy and $20(14.6 \%)$ in fourth or next pregnancy. There were also no significant differences between newborns lipids parameters and pregnancy order or gestational age. The body mass index (BMI) before pregnancy ranged between 20 and $24.9 \mathrm{~kg} / \mathrm{m}^{2}$ in $62.8 \%$ of mothers.

Table 4 Selected risk factors for atherosclerosis in parents (means $\pm \mathrm{SD}) ; 2^{\text {nd }}$ stage of the study

\begin{tabular}{lll}
\hline Parameter & Mothers $(\mathrm{n}=18)$ & Fathers $(\mathrm{n}=18)$ \\
\hline TG $(\mathrm{mg} / \mathrm{dl})$ & $74.56 \pm 25.59$ & $160.00 \pm 84.40$ \\
TC $(\mathrm{mg} / \mathrm{dl})$ & $177.89 \pm 34.28$ & $180.56 \pm 23.82$ \\
HDL $(\mathrm{mg} / \mathrm{dl})$ & $67.77 \pm 19.94$ & $51.07 \pm 15.26$ \\
LDL $(\mathrm{mg} / \mathrm{dl})$ & $95,21 \pm 26.80$ & $97.49 \pm 33.00$ \\
VLDL $(\mathrm{mg} / \mathrm{dl})$ & $14.91 \pm 5.12$ & $32.00 \pm 16.88$ \\
Apo A1 $(\mathrm{mg} / \mathrm{dl})$ & $189.56 \pm 33.71$ & $162.89 \pm 15.73$ \\
Apo B $(\mathrm{mg} / \mathrm{dl})$ & $70.00 \pm 16.24$ & $106.89 \pm 43.78$ \\
Lp $(\mathrm{a})(\mathrm{mg} / \mathrm{dl})$ & $29.60 \pm 34.48$ & $15.43 \pm 14.47$ \\
Hcy $(\mu \mathrm{mol} / \mathrm{L})$ & $11.63 \pm 4.19$ & $15.07 \pm 4.26$ \\
sVCAM-1 $(\mathrm{ng} / \mathrm{ml})$ & $952.98 \pm 249.80$ & $930.41 \pm 492.07$ \\
slCAM-1 $(\mathrm{ng} / \mathrm{ml})$ & $294.50 \pm 62.13$ & $363.93 \pm 134.46$ \\
sE-selectin $(\mathrm{ng} / \mathrm{ml})$ & $29.28 \pm 19.44$ & $34.08 \pm 37.51$ \\
IMT $(\mathrm{mm})$ & $0.59 \pm 0.2$ & $0.61 \pm 0.10$ \\
\hline
\end{tabular}

BMI lower than $19.9 \mathrm{~kg} / \mathrm{m}^{2}$ was reported by 22 women (16.1\%), another 22 (16.1\%) had BMI between 25 to $29.9 \mathrm{~kg} / \mathrm{m}^{2}$ and $7(5.1 \%)$ women were obese (BMI over $30 \mathrm{~kg} / \mathrm{m}^{2}$ ). Table 6 presents newborns' cord blood lipids parameters according to mothers BMI before pregnancy.

\section{Discussion}

The most current American Academy of Pediatrics (AAP) guidelines for cardiovascular health recommend to fasting lipid profile in children at increased risk for CVD for the first time between 2 and 10 years of age. In risk groups are children with: 1 ) a positive family history of dyslipidemia or premature ( $\leq 55$ years of age for men and $\leq 65$ years of age for women) CVD or dyslipidemia, 2) unknown family history, 3) other CVD risk factors, such as overweight (BMI $\geq 85$ th percentile, $<95$ th percentile), obesity (BMI $\geq 95$ th percentile), hypertension (blood pressure $\geq 95$ th percentile), cigarette smoking, or diabetes mellitus [18].

The National Cholesterol Education Program (NCEP) Expert Panel on Blood Cholesterol Levels in Children and Adolescents specify positive family history in biological parents and grandparents for CVD as myocardial infarction, angina pectoris, peripheral or cerebral vascular disease, sudden death, coronary artery bypass-surgery or balloon angioplasty before age 55 [19]. It should be noted that in children CVD risk we evaluate medical history of first and second-degree relatives.

The most remarkable result of our study is significant increase of TG and VLDL serum concentration in children aged 1.5-2.5 years with a family history of premature CAD compared to controls. However we did not 
Table 5 Lipid and apolipoprotein concentrations (means \pm SD) in newborns' cord blood according to birth weight

\begin{tabular}{|c|c|c|c|c|}
\hline Parameter & Birth weight (g) & Newborns (n) & Concentration & $p$ \\
\hline \multirow[t]{5}{*}{$\overline{\mathrm{TG}}(\mathrm{mg} / \mathrm{dl})$} & $2250-2500$ & 12 & $91.83 \pm 75.00$ & $<0.05$ \\
\hline & $2501-3000$ & 36 & $44.97 \pm 22.70$ & $1: 2$ \\
\hline & $3001-3500$ & 44 & $62.39 \pm 94.38$ & $1: 3$ \\
\hline & $3501-4000$ & 36 & $62.14 \pm 53.33$ & $1: 5$ \\
\hline & $4001-4500$ & 9 & $38.44 \pm 6.48$ & $4: 5$ \\
\hline \multirow[t]{5}{*}{$\mathrm{TC}(\mathrm{mg} / \mathrm{dl})$} & $2250-2500$ & 12 & $70.67 \pm 3.44$ & ns \\
\hline & $2501-3000$ & 36 & $63.36 \pm 27.27$ & \\
\hline & $3001-3500$ & 44 & $66.29 \pm 18.94$ & \\
\hline & $3501-4000$ & 36 & $63.14 \pm 18.98$ & \\
\hline & $4001-4500$ & 9 & $65.89 \pm 20.73$ & \\
\hline \multirow[t]{5}{*}{ LDL (mg/dl) } & $2250-2500$ & 12 & $34.41 \pm 10.30$ & ns \\
\hline & $2501-3000$ & 36 & $33.45 \pm 17.94$ & \\
\hline & $3001-3500$ & 44 & $35.84 \pm 13.19$ & \\
\hline & $3501-4000$ & 36 & $32.39 \pm 11.61$ & \\
\hline & $4001-4500$ & 9 & $34.96 \pm 12.19$ & \\
\hline \multirow[t]{5}{*}{ VLDL (mg/dl) } & $2250-2500$ & 12 & $18.37 \pm 15.00$ & $p<0.05$ \\
\hline & $2501-3000$ & 36 & $9.00 \pm 4.58$ & $1: 5$ \\
\hline & $3001-3500$ & 44 & $11.30 \pm 10.57$ & $3: 5$ \\
\hline & $3501-4000$ & 36 & $12.75 \pm 10.58$ & $4: 5$ \\
\hline & $4001-4500$ & 9 & $7.69 \pm 1.30$ & \\
\hline \multirow[t]{5}{*}{$\mathrm{HDL}(\mathrm{mg} / \mathrm{dl})$} & $2250-2500$ & 12 & $17.89 \pm 8.90$ & ns \\
\hline & $2501-3000$ & 36 & $21.16 \pm 7.96$ & \\
\hline & $3001-3500$ & 44 & $19.44 \pm 7.19$ & \\
\hline & $3501-4000$ & 36 & $17.99 \pm 9.05$ & \\
\hline & $4001-4500$ & 9 & $23.24 \pm 9.42$ & \\
\hline \multirow{5}{*}{$\begin{array}{l}\text { Apo A1 } \\
(\mathrm{mg} / \mathrm{dl})\end{array}$} & $2250-2500$ & 12 & $89.17 \pm 10.02$ & ns \\
\hline & $2501-3000$ & 36 & $90.14 \pm 20.41$ & \\
\hline & $3001-3500$ & 44 & $90.25 \pm 18.80$ & \\
\hline & $3501-4000$ & 36 & $89.11 \pm 14.35$ & \\
\hline & $4001-4500$ & 9 & $85.89 \pm 29.25$ & \\
\hline \multirow{5}{*}{$\begin{array}{l}\text { Apo B } \\
(\mathrm{mg} / \mathrm{dl})\end{array}$} & $2250-2500$ & 12 & $47.25 \pm 18.01$ & $<0.05$ \\
\hline & $2501-3000$ & 36 & $33.97 \pm 14.88$ & $1: 2$ \\
\hline & $3001-3500$ & 44 & $35.48 \pm 12.82$ & \\
\hline & $3501-4000$ & 36 & $41.47 \pm 22.27$ & \\
\hline & $4001-4500$ & 9 & $39.33 \pm 20.24$ & \\
\hline
\end{tabular}

ns - non-significant

find any differences in lipid profile in newborns with a positive family history of premature CAD and controls.

Kelishadi et al. reported a significantly higher levels of TG, TC and LDL, and lower levels of HDL in children of parents with premature CAD [20]. Romaldini et al. showed hypercholesterolemia in $27.5 \%$ and hypertriglyceridemia in $12.8 \%$ of children of high-risk families [21]. In young adults aged $19 \quad-30$ years with parental
Table 6 Lipid and apolipoprotein concentrations (means \pm SD) in newborns' cord blood according to maternal pre-pregnancy BMI

\begin{tabular}{|c|c|c|c|c|}
\hline Parameter & BMI $\left(\mathrm{kg} / \mathrm{m}^{2}\right)$ & Newborns (n) & $\mathrm{M} \pm \mathrm{SD}$ & $\mathrm{p}$ \\
\hline \multirow[t]{4}{*}{$\overline{\mathrm{TG}}(\mathrm{mg} / \mathrm{dl})$} & $<19.9$ & 22 & $43.19 \pm 20.73$ & \multirow[t]{4}{*}{ ns } \\
\hline & $20-24.9$ & 86 & $57.36 \pm 49.61$ & \\
\hline & $25-29.9$ & 22 & $82.73 \pm 128.70$ & \\
\hline & $>30$ & 7 & $47.14 \pm 13,80$ & \\
\hline \multirow[t]{4}{*}{ TC (mg/dl) } & $<19.9$ & 22 & $59.00 \pm 17.37$ & \multirow[t]{4}{*}{ ns } \\
\hline & $20-24.9$ & 86 & 65.57 .22 .27 & \\
\hline & $25-29.9$ & 22 & $71.09 \pm 21.53$ & \\
\hline & $>30$ & 7 & $58.71 \pm 11.03$ & \\
\hline \multirow[t]{4}{*}{ LDL (mg/dl) } & $<19.9$ & 22 & $31.78 \pm 13.91$ & \multirow[t]{4}{*}{ ns } \\
\hline & $20-24.9$ & 86 & $34.32 \pm 14.11$ & \\
\hline & $25-29.9$ & 22 & $37.16 \pm 14.62$ & \\
\hline & $>30$ & 7 & $29.53 \pm 7.49$ & \\
\hline \multirow[t]{4}{*}{ VLDL (mg/dl) } & $<19.9$ & 22 & $8.89 \pm 4.20$ & $<0.05$ \\
\hline & $20-24.9$ & 86 & $11.80 \pm 9.97$ & \multirow[t]{3}{*}{$1: 2$} \\
\hline & $25-29.9$ & 22 & $13.32 \pm 13.73$ & \\
\hline & $>30$ & 7 & $9.43 \pm 2.76$ & \\
\hline \multirow[t]{4}{*}{$\mathrm{HDL}(\mathrm{mg} / \mathrm{dl})$} & $<19.9$ & 22 & $18.90 \pm 5.18$ & \multirow[t]{4}{*}{ ns } \\
\hline & $20-24.9$ & 86 & $19.55 \pm 9.46$ & \\
\hline & $25-29.9$ & 22 & $20.61 \pm 7.16$ & \\
\hline & $>30$ & 7 & $19.76 \pm 4.55$ & \\
\hline \multirow[t]{4}{*}{ Apo Al (mg/dl) } & $<19.9$ & 22 & $87.05 \pm 10.80$ & $<0.05$ \\
\hline & $20-24.9$ & 86 & $88.30 \pm 20.08$ & $1: 3$ \\
\hline & $25-29.9$ & 22 & $97.77 \pm 18.69$ & $2: 3$ \\
\hline & $>30$ & 7 & $86.71 \pm 6.56$ & $3: 4$ \\
\hline \multirow[t]{4}{*}{ Apo B (mg/dl) } & $<19.9$ & 22 & $31.55 \pm 6.73$ & $<0.05$ \\
\hline & $20-24.9$ & 86 & $39.64 \pm 20.51$ & $1: 2$ \\
\hline & $25-29.9$ & 22 & $38.95 \pm 13.68$ & $1: 3$ \\
\hline & $>30$ & 7 & $34.00 \pm 7.63$ & \\
\hline
\end{tabular}

ns - non-significant

premature $\mathrm{CAD}$ only $\mathrm{TC}$ concentration was significantly higher than in controls [22]. Marcovecchio et al. reported significant differences regarding TG and HDL between adolescents with a history of parental dyslipidemia and non-risk controls [23]. Mendes et al. revealed higher values of TC and lower of HDL in offspring of young adults with CAD than in controls [24]. It should be noted that our study was conducted only in children aged 1.5-2.5 years and most of mentioned studies were performed among older children and adolescents. Lipids and lipoproteins concentrations are the lowest during intrauterine life and at birth, and then increase until 2 years of age. Human lipid levels became quite constant up to adolescence [25]. Moreover, to understand some of these differences the ethnic and racial disparities should be also taken into consideration. 
Elevated Lp(a) levels have been identified as independent risk factor for CAD that promotes atherogenesis and thrombogenesis [10, 26]. Several studies in children have found a positive association between $\mathrm{Lp}$ (a) level and positive family history of CVD [27-29]. This concept has been challenged by Tonstad et al. demonstrating that $\operatorname{Lp}(\mathrm{a})$ was marginally lower in the children with a history of premature cardiovascular death in male relatives $(p=0.033)$ [30]. In our study children, but not newborns, from kindreds with a history of premature CAD were also distinguished from controls by significantly higher $L p(a)$ levels. Since $L p(a)$ level is fully expressed in the first year of life, has a genetic adjustment, does not vary with age and, is almost unaltered by environmental factors, it should be widely applied to identification children at increased risk of CVD [28].

IMT is a well-established non-invasive marker of cardiovascular risk in adults. It has been showed that IMT $>0.9$ $\mathrm{mm}$ is related to significant atherosclerotic risk in adults [31]. In our study, the mean values of IMT in mothers and fathers did not exceed that cut-off level. Litwin et al. summarize growing body of evidence for increased IMT in children and adolescents with cardiovascular risk factors like obesity, hypertension or hyperlipidemia. It has been also reported that children with parental history of premature myocardial infarction have increased IMT independently of traditional atherosclerotic risk factors [32, 33]. However, it should be highlighted that age is the most important determinant of IMT, and increased IMT mostly was not seen in children under 10 years of age [31]. That fact may explain the lack of differences in IMT between children with a family history of premature CAD and controls in our study. Thus, efforts should be focused on enhance IMT measurements.

Several limitations to this study need to be acknowledged. The final sample size is quite small and there is no control group composed of adults. Moreover, no correction for multiple testing is a limitation. In the second stage of the study we do not evaluate impact of environmental cardiovascular risk factors like diet or physical activity on lipids parameters and IMT. It is suggested that the association of these factors is investigated in future studies. Further investigation, among the same subjects, to determine current cardiovascular risk is strongly recommended.

\section{Conclusions}

The present study make several noteworthy contributions to atherosclerosis research. Measurement of serum $\mathrm{Lp}$ (a) level may be apply to identification cardiovascular risk in children and adolescents. IMT is not a reliable measure of atherosclerosis in the youngest children. Early detection of cardiovascular risk in children with a family history of premature cardiovascular diseases should result in prevention intervention in the entire family.

\section{Abbreviations}

AAP: American Academy of Pediatrics; Apo A1: apolipoprotein A1; Apo B: apolipoprotein B; BMI: body mass index; CAD: coronary artery disease; CVD: cardiovascular disease; Hcy: homocysteine (Hcy); HDL: high density lipoprotein; hs-CRP: high-sensitivity C-reactive protein; IMT: intima-media thickness; LDL: low density lipoprotein; Lp(a): lipoprotein a; NCEP: National Cholesterol Education Program; NHLBI: National Heart, Lung, and Blood Institute; oxy-LDL: oxidized low density lipoprotein; sICAM-1: soluble intercellular adhesion molecule-1; sVCAM-1: soluble vascular cell adhesion molecule-1; TC: total cholesterol; TG: triglycerides; VLDL: very low density lipoprotein

\section{Acknowledgements \\ Not applicable. \\ Funding \\ None. \\ Availability of data and materials \\ The datasets analyzed during the current study are available from the corresponding author on reasonable request.}

\section{Authors' contributions}

EPK and PK designed the study and conducted the collection of data. EPK, PK and EG contributed to the data analysis and interpretation. EPK, PK and EG analyzed the data and drafted the manuscript. EPK, PK and EG proofread the manuscript. All authors read and approved the final manuscript.

\section{Authors' information}

Not applicable.

\section{Ethics approval and consent to participate}

The written informed consent to this research study was obtained from parents. The paper has been approved by Medical University of Lublin Bioethical Committee (number KE-0254/74/2009).

Consent for publication

Not applicable.

\section{Competing interests}

The authors declare that they have no competing interests.

\section{Publisher's Note}

Springer Nature remains neutral with regard to jurisdictional claims in published maps and institutional affiliations.

\section{Author details}

${ }^{1}$ Department of Paediatrics and Gastroenterology, Medical University of Lublin, Gebali 6 Street, 20-093 Lublin, Poland. 'Department of Clinical Immunology and Immunotherapy, Medical University of Lublin, Chodzki 4a Street, 20-093 Lublin, Poland.

Received: 24 July 2016 Accepted: 27 March 2018

Published online: 03 April 2018

References

1. Berenson BS. Cardiovascular risk begins in childhood: A time for action. Am J Prev Med. 2009;37(1S):S1-2.

2. Gidding SS, McMahan CA, McGill HC, Colangelo LA, Schreiner PJ, Williams $\mathrm{OD}$, et al. Prediction of coronary artery calcium in young adults using the Pathobiological Determinants of Atherosclerosis in Youth (PDAY) risk score: the CARDIA study. Arch Intern Med. 2006;166:2271-6.

3. Libby P, Theroux P. Pathophysiology of coronary artery disease. Circulation. 2005;111:3481-8.

4. Weber $\mathrm{C}$, Noels H. Atherosclerosis: current pathogenesis and therapeutic options. Nat Med. 2011;17:1410-22.

5. Singh RB, Mengi SA. Xu YJ, Arneja AS, Dhalla NS. Pathogenesis of atherosclerosis: A multifactorial process. Exp Clin Cardiol. 2002;7:40-53.

6. Libby P. Changing concepts of atherogenesis. J Intern Med. 2000;247: 349-58. 
7. Dawber TR, Kannel WB. The Framingham Study: an epidemiological approach to coronary heart. Circulation. 1966;34:553-5.

8. Kannel WB, McGee D, Gordon T. A general cardiovascular risk profile: The Framingham Study. Am J Cardiol. 1976:38:46-51.

9. Khot UN, Khot MB, Bajzer CT, Sapp SK, Ohman EM, Brener SJ, et al. Prevalence of conventional risk factors in patients with coronary heart disease. JAMA. 2003;290:898-904.

10. Fruchart D, Nierman MC, Stroes ESG, Kastelein JJP, Duriez P. New risk factors for atherosclerosis and patient risk assessment. Circulation. 2004; 109:15-9.

11. Pourebrahim R, Fakhrzadeh H, Bandarian F, Tabatabie O, Noori M, Djalilpour F, et al. Household cardiovascular screening of high-risk families: A schoolbased study. Eur J Cardiovasc Prev Rehabil. 2006;13:229-35.

12. Assimes TL. Family history of heart disease: The re-emergence of a traditional risk factor. J Am Coll Cardiol. 2011;57:628-9.

13. Ripatti S, Tikkanen E, Orho-Melander M, Havulinna AS, Silandere K, Sharma A, et al. A multilocus genetic risk score for coronary heart disease: Casecontrol and prospective cohort analyses. Lancet. 2010;376:1393-400.

14. Jaquith BC, Harris MA, Penprase B. Cardiovascular disease risk in children and adolescents. J Pediatr Nurs. 2013;28:258-66.

15. National Cholesterol Education Program (NCEP) Expert Panel on Detection, Evaluation, and Treatment of High Blood Cholesterol in Adults (Adult Treatment Panel III). The Third Report of the Expert Panel on Detection, Evaluation, and Treatment of High Blood Cholesterol in Adults (Adult Treatment Panel III). Third Report of the National Cholesterol Education Program (NCEP) Expert Panel on Detection, Evaluation, and Treatment of High Blood Cholesterol in Adults (Adult Treatment Panel III) final report. Circulation. 2002;106: 3143-3421.

16. Hunt SC, Gwinn M, Adams TD. Family history assessment: strategies for prevention of cardiovascular disease. Am J Prev Med. 2003;24:136-42.

17. Friedewald WT, Levy RI, Fredrickson DS. Estimation of the concentration of low-density lipoprotein cholesterol in plasma, without use of the preparative ultracentrifuge. Clin Chem. 1972;18:499-502.

18. Daniels SR, Greer FR. The Committee on Nutrition. Lipid screening and cardiovascular health in childhood. Pediatrics. 2008;122:198-208.

19. Dennison BA, Jenkins PL, Pearson TA. Challenges to implementing the current pediatric cholesterol screening guidelines into practice. Pediatrics. 1994;94:296-302.

20. Kelishadi R, Zadegan NS, Naderi GA, Asgary S, Bashardoust N. Atherosclerosis risk factors in children and adolescents with or without family history of premature coronary artery disease. Med Sci Monit. 2002;8: 425-9.

21. Romaldini CC, Issler H, Cardoso AL, Diament J, Forti N. Risk factors for atherosclerosis in children and adolescents with family history of premature coronary artery disease. J Pediatr (Rio J). 2004;80:135-40.

22. Surdacki A, Zawiślak B, Rakowski T, Wieczorek-Surdacka E, Fedak D, Dubiel JS. Parental history of premature coronary artery disease does not affect plasma levels of asymmetric dimethylarginine in young healthy adults. Pol Arch Med Wewn. 2012;122:487-93.

23. Marcovecchio ML, Tossavainen PH, Heywood JJ, Dalton RN, Dunger DB. An independent effect of parental lipids on the offspring lipid levels in a cohort of adolescents with type 1 diabetes. Pediatr Diabetes. 2012;13:463-9.

24. Mendes GA, Martinez TL, Izar MC, Amancio OM, Novo NF, Matheus SC, Bertolami MC, Fonseca FA. Lipid profile and nutrition counseling effects in adolescents with family history of premature coronary artery disease. Arq Bras Cardiol. 2006:86:361-5.

25. Kwiterovich PO. Recognition and management of dyslipidemia in children and adolescents. J Clin Endocrinol Metab. 2008:93:4200-9.

26. Guardamagna O, Abello F, Anfossi G, Pirro M. Lipoprotein(a) and family history of cardiovascular disease in children with familial dyslipidemias. J Pediatr. 2011;159:314-9.

27. Marquez A, Mendoza S, Carrasco H, Hamer T, Glueck CJ. High lipoprotein (a) in children from kindreds with parental premature myocardial infarction. Pediatr Res. 1993;34:670-4.

28. Wilcken DE, Wang XL, Greenwood J, Lynch J. Lipoprotein (a) and apolipoproteins $B$ and $A 1$ in children and coronary vascular events in their grandparents. J Pediatr. 1993;123:519-26.

29. Bailleul S, Couderc R, Rossignol C, Fermanian J, Boutouchent F, Farnier MA Etienne J. Lipoprotein(a) in childhood: relation with other atherosclerosis risk factors and family history of atherosclerosis. Clin Chem. 1995;41:241-5.
30. Tonstad S, Refsum H, Sivertsen M, Christophers B, Ose L, Ueland PM. Relation of total homocysteine and lipid levels in children to premature cardiovascular death in male relatives. Pediatr Res. 1996;40:47-52.

31. Litwin M, Niemirska A. Intima-media thickness measurements in children with cardiovascular risk factors. Pediatr Nephrol. 2009;24:707-19.

32. Morrison KM, Conner DW, Helden E, Newkirk L, Yusuf S, Lonn E. Cardiovascular risk factors and non-invasive assessment of subclinical atherosclerosis in youth. Atherosclerosis. 2010;208:501-5.

33. Barra S, Gaeta G, Cuomo S, Guarini P, Foglia MC, Capozzi G, et al. Early increase of carotid intima-media thickness in children with parental history of premature myocardial infarction. Heart. 2009:95:642-5.

\section{Submit your next manuscript to BioMed Central and we will help you at every step:}

- We accept pre-submission inquiries

- Our selector tool helps you to find the most relevant journal

- We provide round the clock customer support

- Convenient online submission

- Thorough peer review

- Inclusion in PubMed and all major indexing services

- Maximum visibility for your research

Submit your manuscript at www.biomedcentral.com/submit
Biomed Central 